\title{
Redescription and geographic distribution of Raorchestes shillongensis (Anura: Rhacophoridae) from Meghalaya, Northeast India
}

\author{
Bitupan Boruah, ${ }^{1}$ Prudhvi Raj, ${ }^{1}$ Sushil K. Dutta, ${ }^{2}$ and Abhijit Das ${ }^{1}$ \\ 1 Wildlife Institute of India, Chandrabani, Dehradun 248001, Uttarakhand, India. E-mail: abhijit@wii.gov.in. \\ 2 Nature Environment and Wildlife Society, Angul, Odisha, India.
}

\begin{abstract}
Redescription and geographic distribution of Raorchestes shillongensis (Anura: Rhacophoridae) from Meghalaya, Northeast India. Raorchestes shillongensis is a threatened rhacophorid frog endemic to Northeast India. The species is poorly known and systematic information is lacking. We redescribe here the morphology of the species from topotypic material and compare with other Bush Frogs of the region. The locality records from the state of Meghalaya are new. We describe its advertisement call and discuss its phylogenetic position.
\end{abstract}

Keywords: advertisement call, conservation, morphology, phylogeny, Rhacophorinae.

\begin{abstract}
Resumo
Redescrição e distribuição geográfica de Raorchestes shillongensis (Anura: Rhacophoridae) de Meghalaya, nordeste da Índia. Raorchestes shillongensis é um anuro racoforídeo ameaçado e endêmico do nordeste da Índia. A espécie é pouco conhecida, não havendo informação sistemática. Redescrevemos aqui a morfologia da espécie a partir de material topotípico e a comparamos com outros racoforídeos da região. O registro da localidade no estado de Meghalaya é novo. Descrevemos ainda seu canto nupcial e discutimos sua posição filogenética.
\end{abstract}

Palavras-chave: canto nupcial, conservação, filogenia, morfologia, Rhacophorinae.

\section{Introduction}

Sixty-two species of frogs of the genus Raorchestes are known from India, Nepal, Myanmar, Thailand, Laos, Southern China, Vietnam, Cambodia, and West Malaysia (Frost 2017). Four species are reported from Northeast India (Frost 2017). Pillai and Chanda (1973)

Received 14 September 2017

Accepted 02 March 2018

Distributed June 2018 described Philautus shillongensis based on eight specimens collected from Malki Forest, Shillong (1,524 m a.s.1.), Meghalaya, India. Bossuyt and Dubois (2001) commented on the taxonomic identity of the species. Based on the assumptions of Biju et al. (2010), the species is placed in Raorchestes (Frost 2017) by implication. Mahony et al. (2013) considered the species endemic to the Shillong Plateau. Given the scanty information on distribution, ecology, reproductive behavior, and phylogeny of Raorchestes shillongensis (Pillai and Chanda, 1973), we redescribe the species and discuss its systematic relationships. 


\section{Materials and Methods}

\section{Study Area}

The study area is located in the state of Meghalaya in northeast India. The type locality of Raorchestes shillongensis in Malki forest (2533'45" N, 9153'19" E; WGS-84) lies in the Shillong City of East Khasi Hills District (Figure 1). The region receives about $9,000-11,000 \mathrm{~mm}$ of rain annually (Goswami et al. 2012). The Khasi Hills support a subtropical wet hill forest that is dominated by pine trees and considerable amount of grasslands with some scattered, broadleaf trees (Champion and Seth 1968, Mahony et al. 2013).

\section{Field Survey}

We conducted our field study in May and August 2016. Nocturnal visual encounter and acoustic searches were used to locate calling aggregations (Heyer et al. 1994). We recorded data on habitat, microhabitat, perch height, color variation, and behavioral activities. Sex was determined by the presence/absence of a vocal sac and/or mature ova visible externally. Temperature and humidity were recorded with a hygrometer. We surveyed opportunistically to evaluate the distribution of the species, and determined geographical coordinates with a GPS. Adult frogs that were collected were fixed in formalin and preserved in $70 \%$ ethanol. Specimens are housed in the laboratory of Wildlife Institute of India (WII), Dehradun.

Abbreviations.-ZSI (Zoological Survey of India); V/ERS [Voucher/Eastern Regional Station, Shillong (ZSI)].

\section{DNA Extraction and Amplification}

Total genomic DNA was extracted from liver tissues preserved in molecular grade ethanol using a DNeasy blood and tissue kit (Qiagen, Germany) following the manufacturer's protocol. Partial gene fragments of $16 \mathrm{~S}$ rDNA were amplified by polymerase chain reaction (PCR). Primers 5'-GCCTGTTTATCAAAAACAT-3' (16Sar-L) and 5'-CCGGTCTGAACTCAGATCACGT-3' $(16 \mathrm{Sbr}-\mathrm{H})$ as forward and reverse for $16 \mathrm{~S}$ (Palumbi et al. 1991), were used in the current study. Each PCR reaction was prepared in a $25 \mu \mathrm{l}$ volume amplification mixture consisting of $2.5 \mu \mathrm{l}$ $\mathrm{MgCl}_{2}, 2.5 \mu \mathrm{l}$ of Taq polymerase buffer, $2.5 \mu \mathrm{l}$ of dNTPs mix, $0.25 \mu \mathrm{l}$ of each primer (forward and reverse), $1 \mu \mathrm{l}$ of purified DNA, $0.67 \mu \mathrm{l}$ of Taq polymerase (Bangalore GeneiPvt. Ltd.) and Milli-Q water was used to make up the remaining $25 \mu \mathrm{l}$ volume. We amplified the $16 \mathrm{~S}$ rRNA gene sequences in steps described below.

An initial denaturing step at $94^{\circ} \mathrm{C}(4 \mathrm{~min}), 40$ cycles of denaturing at $94^{\circ} \mathrm{C}(45 \mathrm{~s})$, then annealing at $47.1^{\circ} \mathrm{C}(1 \mathrm{~min})$ and extending at $72^{\circ} \mathrm{C}(1 \mathrm{~min})$, and a final extension at $72^{\circ} \mathrm{C}(10$ $\mathrm{min})$. The PCR products thus generated were purified using spin columns. DNA sequences of only the forward strand were obtained using corresponding forward primers. Sequences are deposited in GenBank (accession numbers: SUB 3716157, SUB 3711598, SUB 3716694, SUB 3716575).

\section{Taxon Sampling and Phylogenetic Analyses}

To infer phylogenetic position of the current species, homologous sequences for 16S r RNA gene for 15 species were downloaded from NCBI GenBank database of closely related clades and genera belonging to Asian Bush Frogs, from southern and southeastern Asia. The species for which sequences were downloaded represent Bush Frog clades from the work of Vijayakumar et al. (2016) and Rahim et al. (unpubl. data). Kurixalus eiffingeri (Boettger, 1895) (Rhacophoridae) was used as outgroup. We also used two sequences from the present study belonging to $R$. shillongensis collected from type locality (Malki Forest) and Risa Forest. And last, we added sequences from one specimen from Riwai and one specimen from Mawlynong, belonging to the genus 

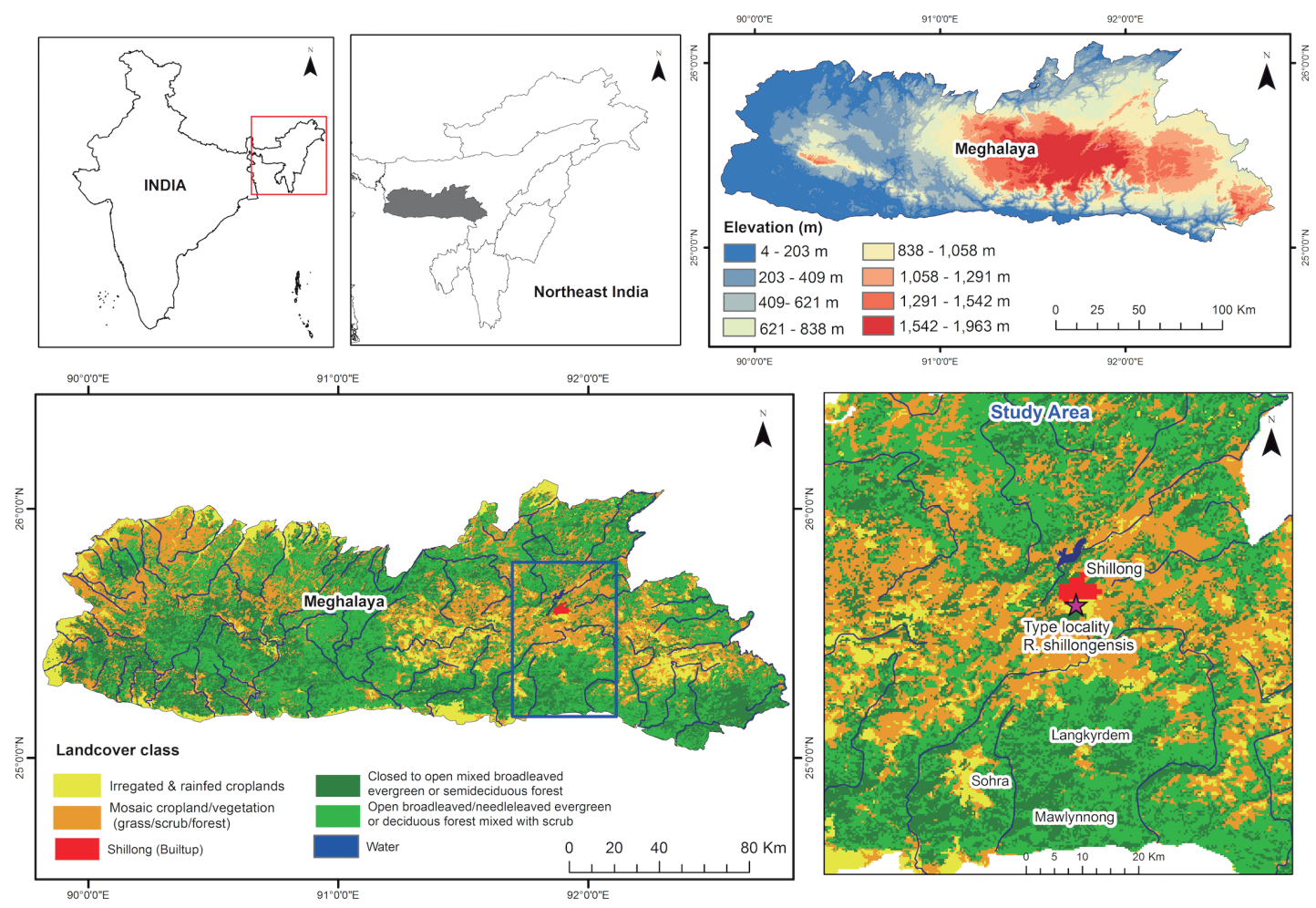

Figure 1. Map showing study area with type locality of Raorchestes shillongensis.

Raorchestes to include taxonomic representation of anurans from different locations within the distributional range of $R$. shillongensis. A total of 19 sequences was used in the current analysis.

Program Muscle (Edgar 2004) implemented in MEGA 7 was used to align our new sequences against these data manually. The alignments were checked visually and corrected manually if necessary. Alignment gaps were treated as missing data. The final alignment consisted of 486 base pairs. Accession numbers of new sequences generated in the study, as well as those that were downloaded from GenBank for phylogenetic analysis, are listed in Appendix I. The phylogenetic analysis was performed by Maximum Likelihood (ML). We performed
JModelTest to determine appropriate evolutionary models for the nucleotide and GTR+I was selected based on Akaike information Criterion (AIC). ML analyses were conducted using program RAxML 8.0.0 (Stamatakis 2014) on the dataset. GTR + I nucleotide substitution model was used for all subsets, and support for nodes of the resulting ML trees was assessed by analyses of 1000 bootstrap iterations.

\section{Morphometrics}

Frogs were measured to the nearest $0.1 \mathrm{~mm}$ with digital callipers within 2 months of preservation. Abbreviations: SVL, snout-vent length (from tip of snout to vent); SL, snout 
length (from anterior corner of eye to tip of snout); IOS, interorbital space (least distance between upper eyelids); ED, eye diameter (horizontal); UEW, upper eyelid width (maximum transverse distance of the upper eyelid measured from inner edge to outer edge); AJS, Angle of jaw to snout (distance between angle of jaws and tip of snout); HL, head length (distance between mandible and snout tip); HW, head width (at angle of jaw); FLL, forelimb length (from proximal end of junction of arm with the body to tip of the Finger III); F-I to F-IV, lengths of $1^{\text {st }}$ to $4^{\text {th }}$ fingers (from the base of the palm to the tip of the respective finger); HLL, hind-limb length (from midventral line of attachment of legs with body to tip of the $4^{\text {th }}$ toe); TL, thigh length (distance from the middle of vent to knee); TBL, tibia length (distance between surface of knee and surface of heel, with both tibia and tarsus flexed); T-I to T-V, lengths of $1^{\text {st }}$ to $5^{\text {th }}$ toes (from the inner metatarsal tubercle region to tip of the respective toe); TTA, tibiotarsal articulation (not measured; character used to gauge position of the tibiotarsal articulation when hind limb is stretched parallel to the body).

\section{Call Recording and Analysis}

The call of a single uncollected male Raorchestes shillongensis was recorded with a digital recorder (Sony IC recorder 7.4.0) in Eastern Regional Station, Shillong (Zoological Survey of India) on 30 August 2016 at 19:41 h. The microphone was approximately $1-1.5 \mathrm{~m}$ away from the calling male. Ambient air temperature of the calling site was taken with a digital thermometer. We used Raven Pro Ver. 1.5 (Charif et al. 2010, Bioacoustics Research Program 2011) for call analysis. We measured a total of five temporal properties that included call-group duration, inter-call group interval, intra-call group interval, call duration, and call rate of a call bout comprising of five call groups. One spectral property (viz., peak frequency) was measured for the entire series of calls.
Terminology and graphical representation of call properties analyzed follow those of Bee et al. (2013 a, b).

\section{Maps and Distribution}

Geographic range and point-location maps were generated in ArcGIS 10.3. Open source data from Global Administrative area (www. gadm.org) are used for an administrative boundary, and SRTM 90-m database (http:// srtm.csi.cgiar.org) was used for elevation map. The area under minimum convex polygon (MCP) was computed by connecting the outermost occurrence points to estimate the extent of occurrence.

\section{Results}

Raorchestes shillongensis (Pillai and Chanda, 1973)

Philautus shillongensis Pillai and Chanda, 1973 Philautus (Philautus) shillongensis Bossuyt and Dubois, 2001.

Pseudophilautus shillongensis Li, Che, Murphy, Zhao, Zhao, Rao, and Zhang, 2009.

Raorchestes shillongensis Biju, Shouche, Dubois, Dutta, and Bossuyt, 2010.

Holotype ZSI A6971 (ex V/ERS 472).Collector: R. Giri in 1971, from Malki Forest (GPS point not available), about $3 \mathrm{~km}$ E Risa Colony where Eastern Regional Station of ZSI is situated (Figure 2). Specimens were collected from a hill slope that was cut for the construction of road and about $100 \mathrm{~m}$ away from a moderate flowing stream.

Condition of the holotype: lower mandible broken below left eye, eye damaged; toe discs emaciated; and mouth open and tongue protruding. Color in preservative: body light brown; upper eyelids black; a dark line between upper eyelids; and bands on limbs dark brown.

The topotypic material collected from Risa Forest (WII 500-WII 522) and Malki (WII 523WII 525) of the Shillong Plateau resembles the 
original description by Pillai and Chanda (1973), as follows: relatively small body (SVL of both males and females ranging from 14.21-21.26 $\mathrm{mm})$; nostril closer to snout than eye; snout pointed and little longer than eye diameter; eye pupil horizontal; loreal concave; vomerine teeth absent; tongue without papilla and bifid; a dark line between upper eyelids; $3^{\text {rd }}$ finger longest; $4^{\text {th }}$ toe longest; finger and toe discs rounded. The original description reports a skin fold from eye to shoulder, perhaps about supratympanic fold. We observed the following differences from the original description: dorsolateral fold absent; tympanum indistinct; and both inner and outer metatarsal tubercles absent.

The frogs collected from Riwai, Mawlynnong and Nongkhyllem distinctly differ morphologically and genetically from Raorchestes shillongensis (Table 1).

\section{Redescription Based on Recently Collected Frogs}

Voucher specimens.-(WII 500-WII 525): collected from Risa Colony (2533'41.8" N, 91 ${ }^{\circ} 53^{\prime} 39.1^{\prime \prime}$ E; $25^{\circ} 33^{\prime} 24.4^{\prime \prime} \mathrm{N}, 9^{\circ} 53^{\prime} 33.9^{\prime \prime} \mathrm{E} ; 2^{\circ} 32^{\prime} 39.7^{\prime \prime} \mathrm{N}$,

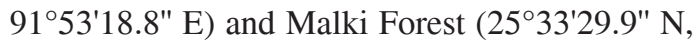
91 ${ }^{\circ} 53^{\prime} 3.8^{\prime \prime}$ E) during study period. Specimens are deposited in Wildlife Institute of India, Dehradun.

Diagnosis.-Redescription based on 25 males and 12 females. A small frog (male SVL 14.2$19.1 \mathrm{~mm}$; female SVL 16.0-21.3 mm). Head length slightly greater than width; snout pointed, protruding slightly beyond mouth in ventral view; loreal region concave, SL slightly larger than ED; IOS larger than ES; IOS larger than UEW; pupil horizontal; nostril closer to tip of snout than to eye; tongue notched; tympanum indistinct; supratympanic fold distinct from posterior corner of upper eyelid to shoulder region; dorsal skin covered with tiny warts; warts may form middorsal ridge on head and forebody; venter and flanks smooth with black blotches; toes webbed, lateral dermal fringe absent along Toe V; discs rounded; tibia longer than thigh; reduced webbing; subarticular
A
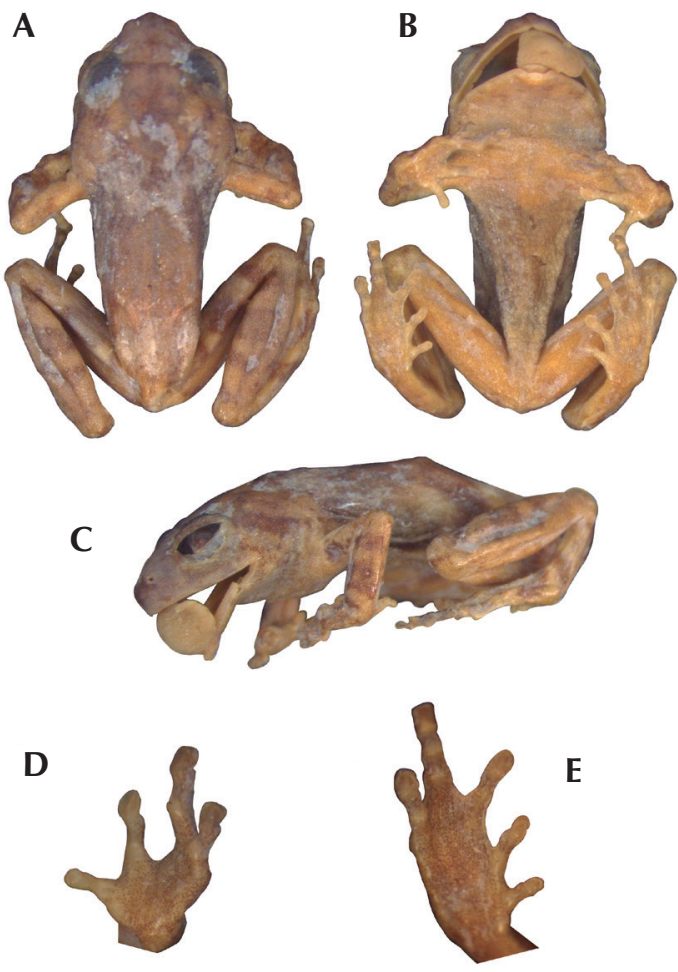

Figure 2. Holotype (ZSI A6971) of Raorchestes shillongensis (17 mm SVL). (A) dorsal view, (B) ventral view, (C) lateral view, (D) ventral view of hand, and (E) ventral view of foot.

tubercle prominent, rounded; metatarsal tubercle absent; toe tips with distinct rounded discs; circummarginal grooves present on finger and toe discs.

Description of an adult male.-(Voucher number WII 503, Figure 3, all measurements in $\mathrm{mm})$ : small $(\mathrm{SVL}=19.1)$; head longer than wide $(\mathrm{HL}=7.0 ; \mathrm{HW}=6.7)$; snout pointed in both dorsal and ventral views; upper jaw protruding slightly in ventral view; snout slightly longer eye diameter $(\mathrm{SL}=2.9 ; \mathrm{ED}=2.4$ ); distance between angle of jaw to tip of the snout 5.2; canthus rostralis distinct; loreal region concave; interorbital space $1.9 \times$ larger than upper eyelid width (IOS = 3.0; UEW = 1.4); nostrils oval, lacking flap, closer snout tip than to eye; tongue distinctly notched; lingual papillae 
Boruah et al.

Table 1. Morphometric measurements $(\mathrm{mm})$ of Raorchestes shillongensis.

\begin{tabular}{|c|c|c|c|c|}
\hline \multirow[t]{2}{*}{ Character } & \multicolumn{2}{|c|}{ Female $(N=12)$} & \multicolumn{2}{|c|}{ Male $(N=25)$} \\
\hline & Range & Mean \pm SD & Range & Mean \pm SD \\
\hline SVL & $15.99-21.26$ & $18.47 \pm 1.6$ & 14.21-19.09 & $16.51 \pm 1.29$ \\
\hline HW & $5.75-7.23$ & $6.45 \pm 0.53$ & $4.33-6.68$ & $5.81 \pm 0.53$ \\
\hline $\mathrm{HL}$ & $5.79-7.24$ & $6.65 \pm 0.49$ & $5.09-7.05$ & $5.9 \pm 0.49$ \\
\hline ED & $2.07-2.76$ & $2.39 \pm 0.2$ & $1.56-2.68$ & $2.08 \pm 0.3$ \\
\hline SL & $2.1-3.23$ & $2.58 \pm 0.39$ & $1.72-2.91$ & $2.19 \pm 0.32$ \\
\hline AJS & $4.47-6.02$ & $5.41 \pm 0.51$ & $3.94-5.7$ & $4.92 \pm 0.4$ \\
\hline IOS & $2.01-3.27$ & $2.54 \pm 0.37$ & $1.47-2.98$ & $2.23 \pm 0.33$ \\
\hline UEW & $1.08-1.61$ & $1.32 \pm 0.18$ & $0.84-2.46$ & $1.23 \pm 0.31$ \\
\hline AG & $7.74-12.7$ & $9.92 \pm 1.25$ & $6.44-10.62$ & $8.39 \pm 1.11$ \\
\hline FLL & $10.61-12.94$ & $11.59 \pm 0.75$ & $8.16-12.91$ & $11.34 \pm 1.27$ \\
\hline F I & $2.11-3.57$ & $2.81 \pm 0.52$ & $1.56-3.84$ & $2.77 \pm 0.62$ \\
\hline FIDW & $0.43-1$ & $0.75 \pm 0.16$ & $0.31-1$ & $0.63 \pm 0.17$ \\
\hline F II & $3.29-5.49$ & $4.4 \pm 0.63$ & $2.76-5.59$ & $4.25 \pm 0.68$ \\
\hline F II DW & $0.45-1.46$ & $0.98 \pm 0.3$ & $0.4-1.43$ & $0.81 \pm 0.31$ \\
\hline F III & $4.97-8.65$ & $6.76 \pm 1.1$ & $4.82-8.66$ & $6.71 \pm 0.93$ \\
\hline F III DW & $0.81-1.75$ & $1.31 \pm 0.29$ & $0.38-1.75$ & $1.13 \pm 0.41$ \\
\hline F IV & $4.21-7.87$ & $5.9 \pm 1.08$ & $3.76-7.34$ & $5.68 \pm 0.9$ \\
\hline F IV DW & $0.56-1.84$ & $1.18 \pm 0.37$ & $0.4-1.76$ & $1.01 \pm 0.36$ \\
\hline TBL & $7.8-9.68$ & $8.73 \pm 0.58$ & $6.37-8.66$ & $7.76 \pm 0.57$ \\
\hline TL & $5.99-8.37$ & $7.18 \pm 0.76$ & $5.37-7.82$ & $6.5 \pm 0.53$ \\
\hline HLL & $23.92-30.03$ & $26.92 \pm 2.17$ & $21.92-27.66$ & $24.63 \pm 1.98$ \\
\hline T I & $1.61-4.26$ & $2.72 \pm 0.79$ & $1.64-2.98$ & $2.47 \pm 0.4$ \\
\hline TIDW & $0.49-1.02$ & $0.71 \pm 0.19$ & $0.36-0.96$ & $0.61 \pm 0.16$ \\
\hline T II & $2.96-5.93$ & $4.08 \pm 0.89$ & $2.61-4.47$ & $3.73 \pm 0.54$ \\
\hline T II DW & $0.54-1.19$ & $0.84 \pm 0.21$ & $0.35-1.07$ & $0.7 \pm 0.2$ \\
\hline T III & $4.47-8.9$ & $6.45 \pm 1.17$ & $4.52-7.12$ & $5.87 \pm 0.85$ \\
\hline T III DW & $0.43-1.37$ & $0.89 \pm 0.28$ & $0.33-1.03$ & $0.76 \pm 0.22$ \\
\hline T IV & 5.9-10.92 & $8.76 \pm 1.5$ & $6.05-10.43$ & $8.04 \pm 1.28$ \\
\hline TIV DW & $0.51-1.76$ & $0.97 \pm 0.36$ & $0.43-1.33$ & $0.89 \pm 0.26$ \\
\hline $\mathrm{T} V$ & $5.23-9.64$ & $7.07 \pm 1.22$ & $4.74-8.37$ & $6.57 \pm 0.91$ \\
\hline T V DW & $0.39-1.53$ & $0.99 \pm 0.35$ & $0.35-1.32$ & $0.8 \pm 0.3$ \\
\hline
\end{tabular}


absent; vomerine teeth absent; tympanum indistinct; supratympanic fold distinct; eyes small, pupil horizontal. Distance between axilla and groin 10.6. Forelimb length 11.9; fingers lacking lateral dermal fringe and web; subarticular tubercles prominent (fingers: $\mathrm{I}=1$, $\mathrm{II}=1$, III $=2$, IV $=1)$; relative lengths of fingers: $\mathrm{I}<\mathrm{II}<\mathrm{IV}<\mathrm{III}(\mathrm{FI}=3.6$, FII $=5.6$, FIII $=8.6$, FIV $=6.9$ ); discs rounded (finger: $\mathrm{I} \mathrm{DW}=$ 0.7 , II DW = 1.1, III DW = 2.0, IV DW = 1.3); circummarginal grooves present; nuptial pad absent. Tibia slightly longer than thigh $(\mathrm{TBL}=$ $8.5, \mathrm{TL}=6.8$ ); supernumerary tubercles and subarticular tubercle present (toe: $\mathrm{I}=1, \mathrm{II}=1$, $\mathrm{III}=2, \mathrm{IV}=3, \mathrm{~V}=2$ ); Toe $\mathrm{V}$ shorter than Toe III $(\mathrm{TV}=6.4$, TIII $=6.75)$; relative lengths of toes: $\mathrm{I}<\mathrm{II}<\mathrm{III}<\mathrm{V}<\mathrm{IV}(\mathrm{TI}=2.03$, TII $=3.76$, $\mathrm{TIII}=6.75, \mathrm{TIV}=8.78, \mathrm{TV}=6.4)$; no lateral dermal fringe along Toe V; webbing reduced, reaching second subarticular tubercle medially, and below second subarticular tubercle along lateral edge of Toe IV; subarticular tubercles prominent, rounded; both inner and outer metatarsal tubercles absent; toe tips with distinct, rounded disks (toe: $\mathrm{I} \mathrm{DW}=0.76$, II DW $=0.6$, III DW $=0.91$, IV DW = 1.2, V DW = 0.69); circummarginal grooves present.

Color in life.-Individuals vary in color (Figure 4). The most consistent and obvious character to identify Raorchestes shillongensis in the field is the presence of a )-( or )(-shaped dark brown mark on the dorsum. The pattern may be distinct or faint. Dark brown or black reticulations along the flank are more pronounced on the groin; dorsum is brown to dark brown.

The following patterns and colors may or may not be present in life: (1) band from axilla to dorsum; (2) dark brown below eye and tympanic fold; (3) fingers and toes discs reddish or whitish; (4) supratympanic fold whitish; (5) dark brown line from below the eye to upper lip; (6) brown line between the upper eyelids; (7) dorsum gray with yellowish hourglass-shaped marking; and (8) dorsum creamy white with dark brown hourglass-shaped marking.

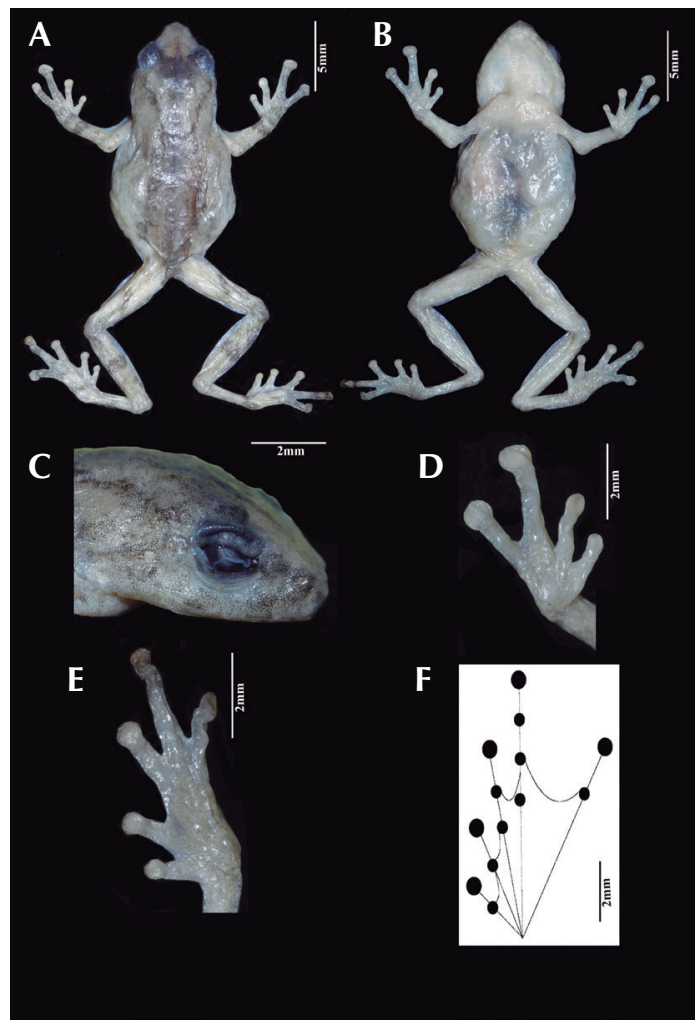

Figure 3. Raorchestes shillongensis (voucher number WII 503). (A) dorsal view, (B) ventral view, (C) lateral view of head, (D) ventral view of hand, (E) ventral view of foot, and (F) web pattern in foot.

Color in preservative.-Dorsal color gray or light brown to dark brown, flanks pale. Prominent dorsal markings and bands on limbs dark brown or black. Anterior part of the head darker, or rarely paler, than rest of body. Triangular dark brown mark with posterior apex between upper eyelids, not visible in life. Eyelids and tympanic fold blackish or brown.

Secondary sexual characters.-Vocal sac transparent and extended. Males (14.2-19.1 mm; $N=25)$ smaller than females $(16.0-21.3 \mathrm{~mm}$; $N=12)$. 


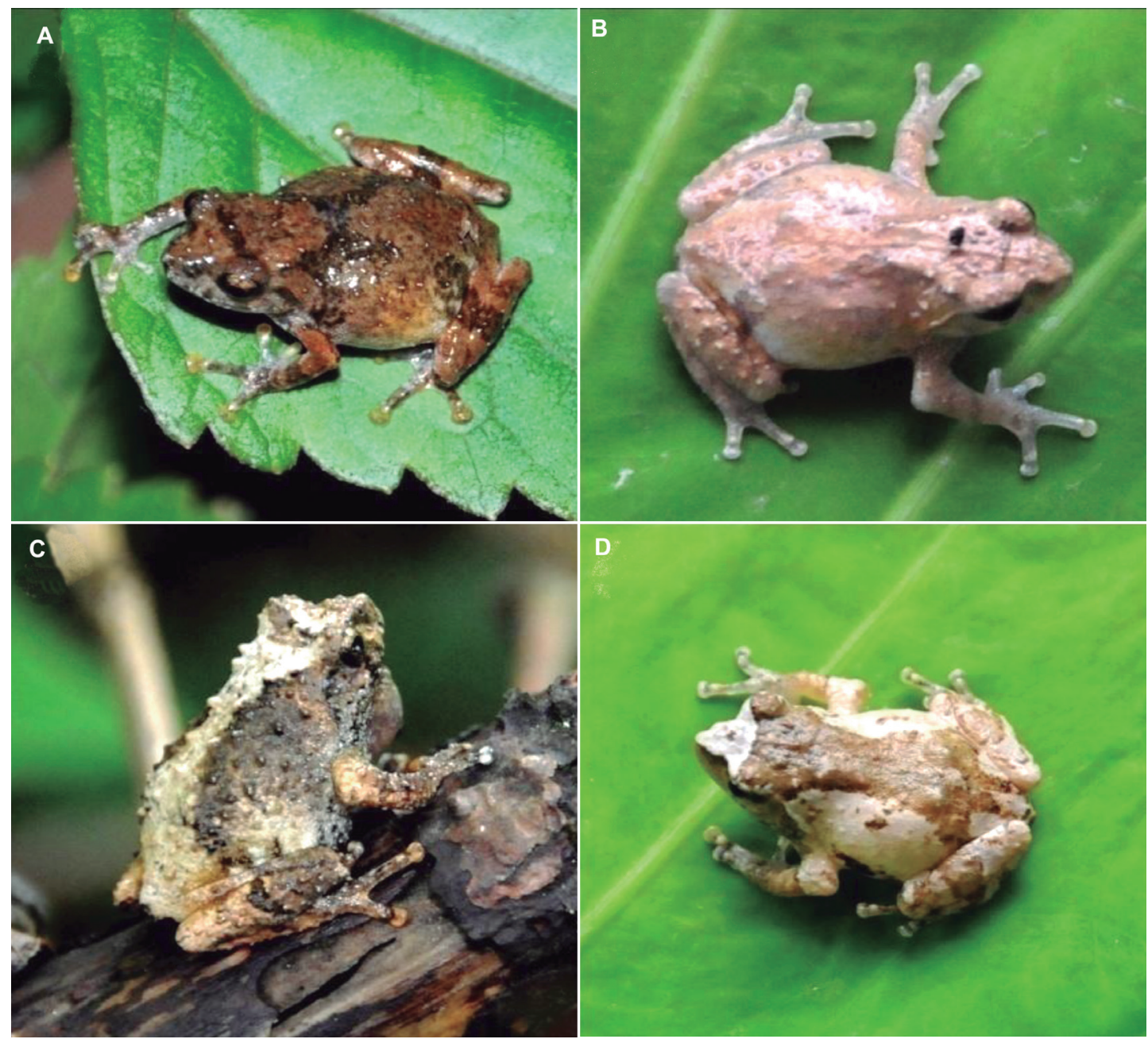

Figure 4. Different color morphs in Raorchestes shillongensis. Photographs were obtained from non-collected specimens at Risa Forest (A and C); Laitkor (B); Malki Forest (D).

\section{Molecular Phylogenetic Position}

The primers amplified approximately $550 \mathrm{bp}$ long portions of the respective $16 \mathrm{~S}$ gene; however, in the current analysis only $486 \mathrm{bp}$ were used. ML analyses on the dataset yielded similar topologies having good bootstrap support at major nodes. In the phylogeny recovered from the ML analysis, Raorchestes shillongensis is a member of the south Asian clade (Raorchestes) rather than the Southeast Asian clade (Philautus); specimens collected from four sites (Malki, Risa Forest, Riwai, and Mawlynnong) represent two species. Risa Forest material (topotypic) resembles that of Malki Forest; thus, these populations are regarded as $R$. shillongensis, a species shown to be more closely related to $R$. longchuanensis (Yang and $\mathrm{Li}, 1978$ ) in southern 
China than to the peninsular Indian clade of Raorchestes. The results from ML analyses of concatenated gene sequences of 16S rRNA genes are shown in Figure 5.

\section{Differential Diagnosis}

Raorchestes shillongensis differs from other members of Raorchestes and Philautus in Northeast India; parenthetical characters refer to congener being compared with $R$. shillongensis. It can be distinguished from Raorchestes sp. 1 collected from Riwai and Mawlynnong by the following characters: smaller body size; tibia shorter than length of Toe IV; middorsal ridge absent; no ridge on thigh and tibia; dark reticulation in groin; TTA reaches tympanic region [vs. large body $(16.23-20.35 \mathrm{~mm}, N=$ 15), tibia longer than Toe IV, distinct or less distinct middorsal ridge from snout to vent, ridge present on thigh and tibia, reticulation absent, TTA reaches eye]. Raorchestes shillongensis differs from Raorchestes sp. 2 (from Nongkhyllem) by the following characters: smaller body size; head longer than wide; nostril closer to snout than eye; supratympanic fold distinct; TTA reaching tympanic region, $)(-$ shaped mark present on back [vs. large body size (17.81-20.08 mm, $N=2$ ), head wider than long, nostril equidistant from snout and eye, supratympanic fold indistinct, TTA reaching the eye, $)$ (-shaped mark absent]. It can be distinguished from $R$. manipurensis (Mathew and Sen, 2009) by: head longer than wide, tongue

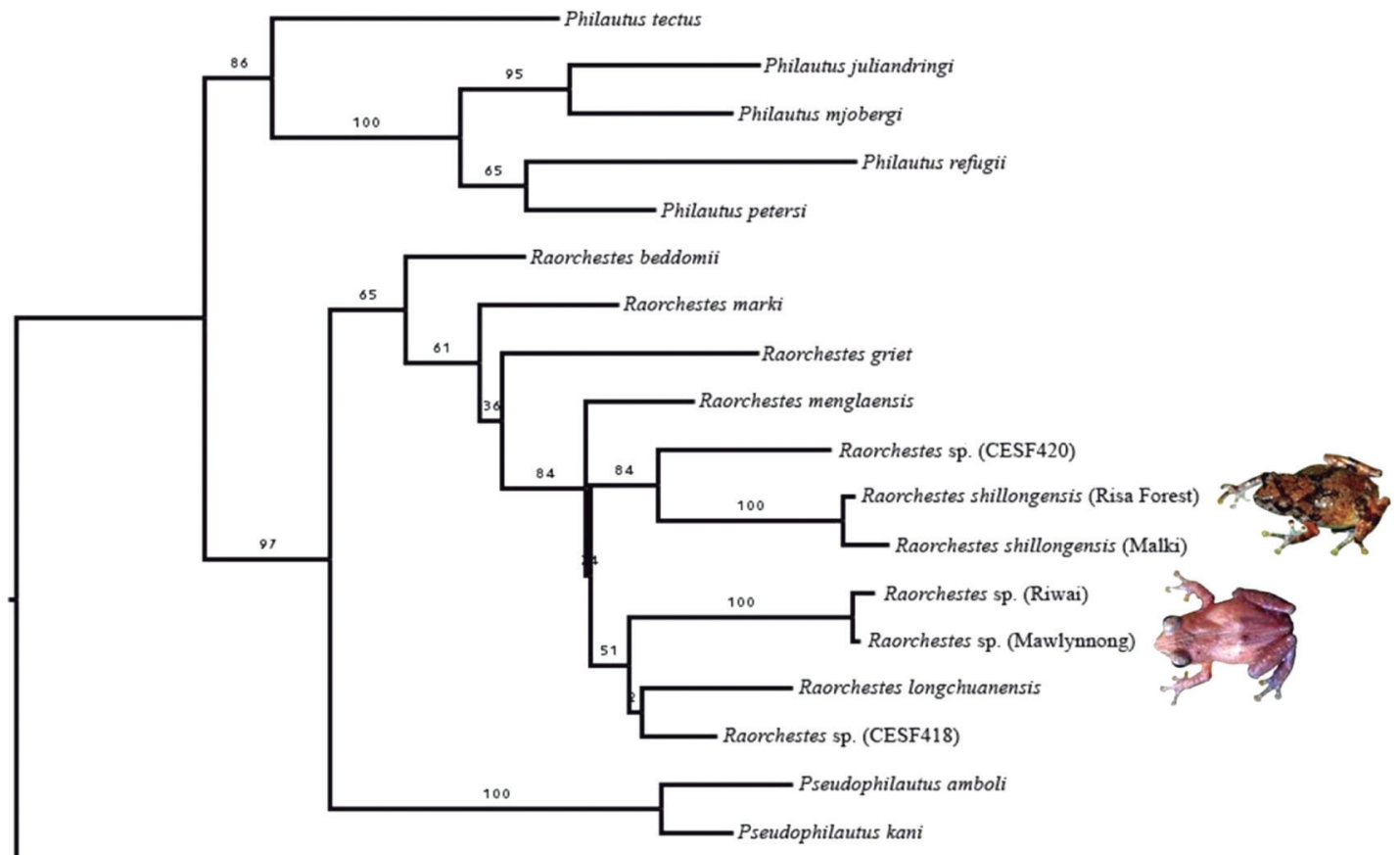

Kurixalus effingeri

$$
0.04
$$

Figure 5. Maximum Likelihood tree for 16 Bush frog species and Kurixalus effingeri as outgroup. Numbers on nodes indicates bootstrap support for Maximum Likelihood. 
bifid, tibia longer than thigh, nostril closer to snout than to eye (vs. head wider than long, tongue lobed, tibia shorter than thigh, nostril equidistant to eye and snout). The species differs from $R$. annandalii (Boulenger, 1906) by: nostril closer to snout than eye, TTA reaches tympanic region (vs. nostril equidistant from snout and eye, TTA reaches tip of snout) and from $R$. sahai (Sarkar and Ray, 2006) by: pointed snout, IOS larger than UEW, nostril closer to snout than to eye (vs. snout rounded, IOS smaller than UEW, nostril equidistant from snout and eye). Raorchestes shillongensis differs from Philautus microdiscus (Annandale, 1912) by: pointed snout, IOS broader than ED (vs. snout rounded, IOS is as wide as ED) and from $P$. garo (Boulenger, 1919) by: TTA reaching tympanic region (vs. TTA reaching anterior corner of the eye). It differs from $P$. kempiae (Boulenger, 1919) by: IOS broader than ED (vs. IOS smaller than ED) and from $P$. namdaphaensis Sarkar and Sanyal, 1985 by nostril closer to snout, TTA reaching tympanic region, middorsal line absent (vs. equidistant from eye and snout, TTA reaching between eye and nostril, mid dorsal line present). The species can be distinguished from P. dubius (Boulenger, 1882) by: absence of papilla in tongue, pointed snout (vs. papilla present, rounded snout) and from $P$. kempii (Annandale, 1912) by the pointed snout, distinct supratympanic fold, TTA reaching tympanic region (vs. rounded snout, supratympanic fold absent, TTA reaching tip of snout). Table 2 summarizes mensural and meristic data for adult Raorchestes shillongensis and those of other Bush Frogs (Raorchestes and Phillautus) that occur in Northeast India.

\section{Advertisement Call}

Calling males emerge at dusk $(18: 30 \mathrm{~h})$ and vocalize until 24:00 h. If it is raining, calling activity from bushy thickets often continues during the day. Advertisement calls occur in call groups (Figure 6) and consist of two to multiple calls. Duration of the call analyzed is $22.62 \mathrm{~s}$; the number of call group is five with call numbers varying from $3-5$. The duration of call group is $0.72 \pm 0.21 \mathrm{~s}(N=5)$ and it varies with the number of calls. The interval between call groups is $4.76 \pm 0.76 \mathrm{~s}(N=4)$, whereas the interval within a call group is $0.19 \pm 0.02 \mathrm{~s}(N=14)$. Each call has a brief single pulse (non-pulsatile) of $0.05 \pm 0.01 \mathrm{~s}(N=19)$. Overall peak frequency of the calls is $3.62 \mathrm{kHz}$.

\section{Natural History}

Raorchestes shillongensis became active with the onset of rain in the last week of April 2016. Frogs were found in human settlements, gardens, roadside shrubs (Eupatorium sp. and ferns), stream sides, and broadleaf forest areas. Individuals perch on leaves and branches of small trees and trunks of pine trees. Males perch $69.2 \pm 38.73 \mathrm{~cm}(N=73)$ above the ground, and females perch $52.53 \pm 42.02 \mathrm{~cm}(N=15)$ above the ground. The females lay $8-17$ eggs on moist soil under leaf litter and the egg undergoes direct development for $30.5 \pm 0.71$ days $(N=2)$. The reproductive mode of $R$. shillongensis is Mode 17 (Duellman and Trueb 1986)-i.e. direct development on ground (Boruah et al. 2017).

\section{Distribution}

We added 82 new localities to the $531-\mathrm{km}^{2}$ range of $R$. shillongensis (Appendix II, Figure 7). The present distribution includes Mawlai Reserve Forest, Laitkor Reserve Forest, Mawpat Reserve Forest, and Upper Shillong Reserve Forest, along with some community conserved and semi-protected forests, such as Mawphlang Sacred Grove and North Eastern Hill University (NEHU) campus. Some tourist spots within the distribution range of $R$. shillongensis are Cherrapunjee, Elephant Falls, Shillong Peak, Happy Valley, and Dainthlen. The species is restricted to an altitudinal range from 1087-1924 $\mathrm{m}$ a.s.l. 


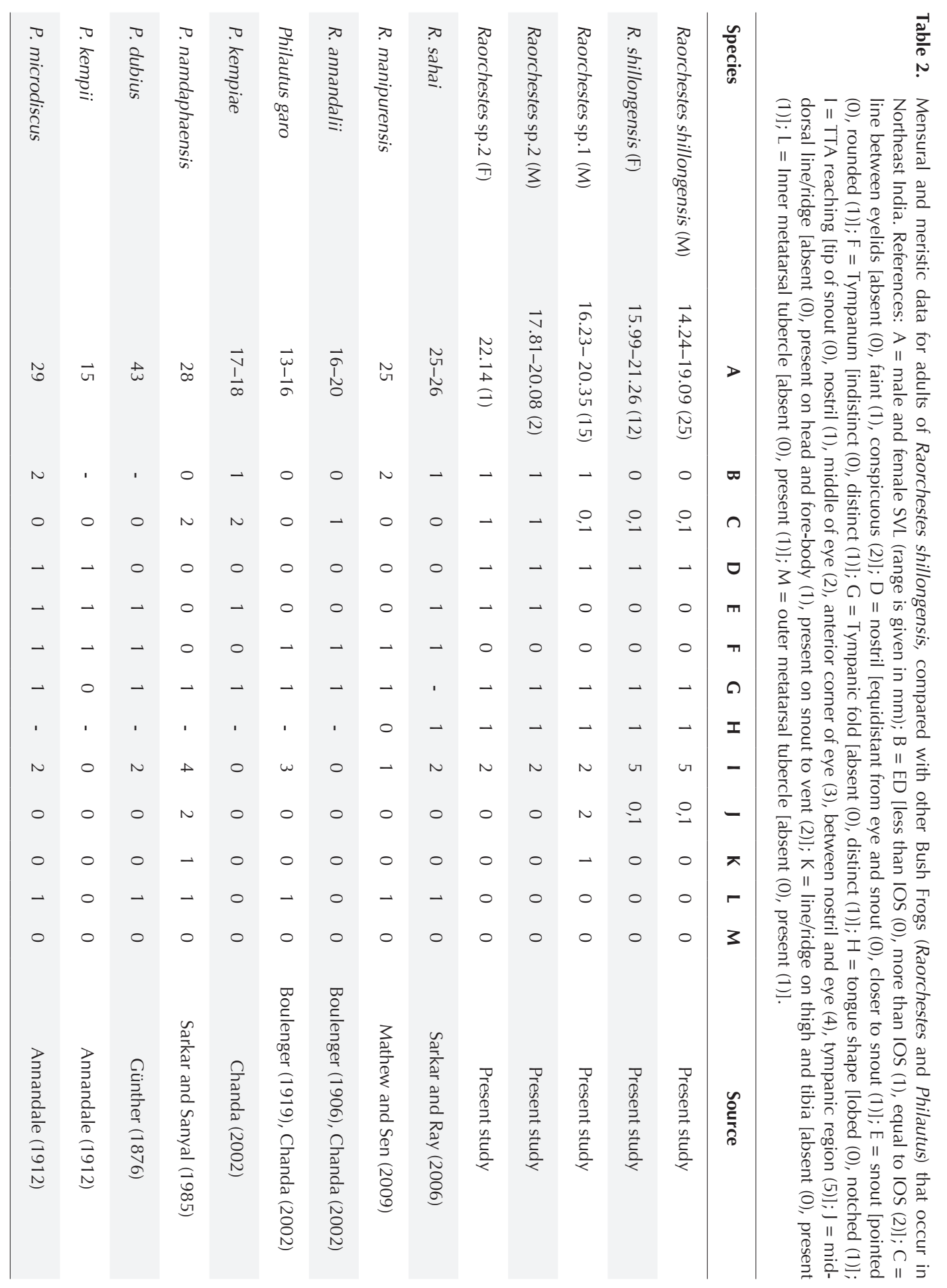



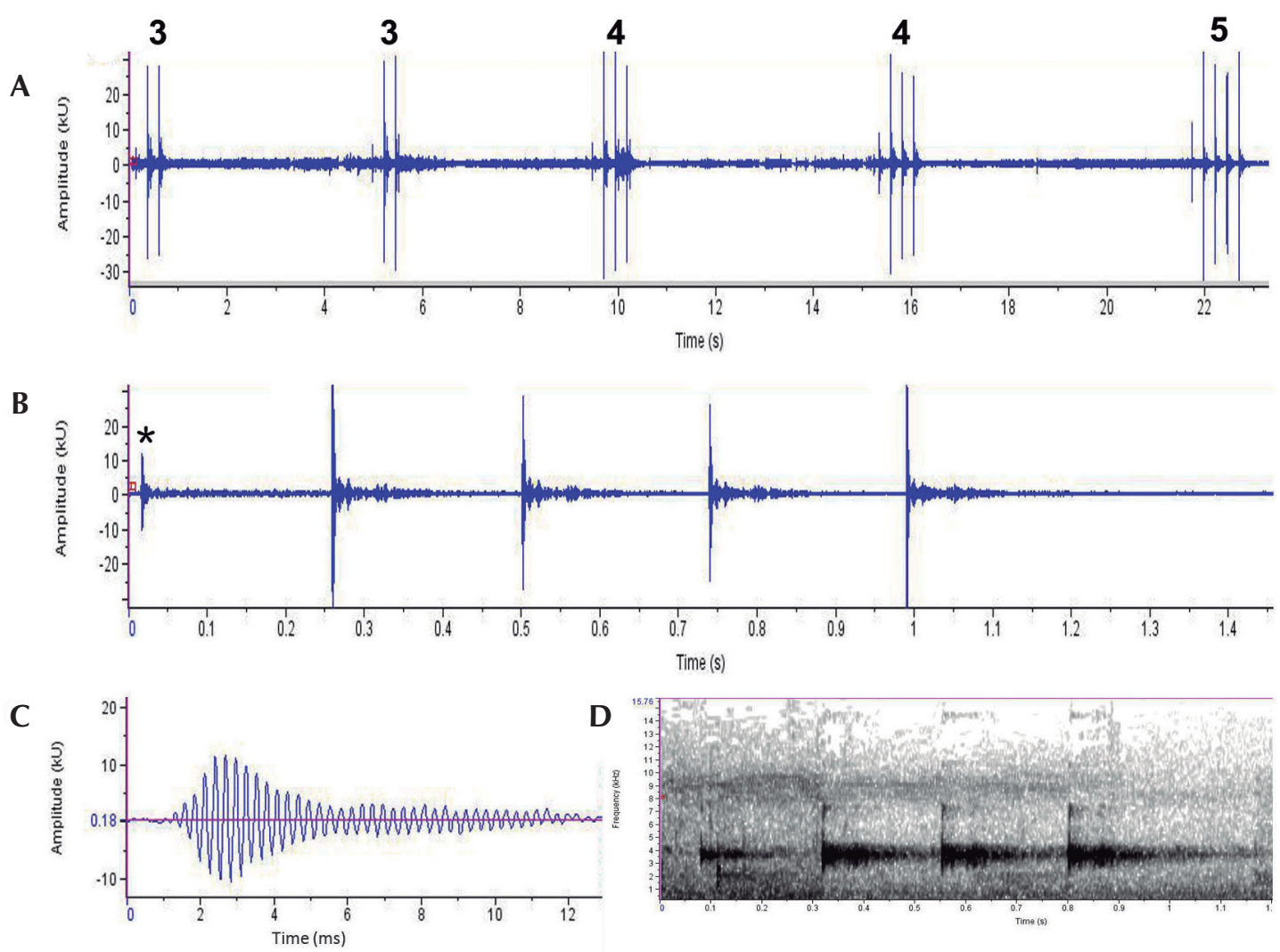

Figure 6. Advertisement call of Raorchestes shillongensis at ambient air temperature $24.1^{\circ} \mathrm{C}$. (A) A call comprising five call groups (numbers indicate number of calls in the respective call group). (B) Showing of $5^{\text {th }}$ (last) call group with five calls depicted in (A). (C) Showing $1^{\text {st }}$ call (non-pulsatile) depicted in (B) (indicated by asterisk). (D) Spectrogram of $4^{\text {th }}$ call group with four calls depicted in (A).

\section{Discussion}

Northeastern Indian anurans are poorly known, as evidenced by the numerous discoveries of new amphibian species in the last $5 \mathrm{yr}$ (Mahony et al. 2011, 2013, Sondhi and Ohler 2011, Kamei et al. 2012, 2013, Purkayastha and Matsui 2012, Das et al. 2013, Biju et al. 2016). Of the 62 species of Raorchestes, 45 have been described in the last $15 \mathrm{yr}$. This reflects increased research interest with this group of anurans in which much diversity probably remains to be revealed.
Photographs of living $R$. shillongensis are available in Ahmed et al. (2009) and Mathew and Sen (2010). Mathew and Sen (2010) mentioned the distribution of $R$. shillongensis in Mizoram, without providing a voucher specimen and collection locality; therefore, we could not include this record in the distribution map of the species. We have confirmed the distribution of the species from Mawlai Reserve Forest in the north to Cherrapunjee in the south of Meghalaya (Figure 7). The species is restricted to altitudes between 1000 and $1900 \mathrm{~m}$ a.s.l. Our frogs from the south (Riwai and Mawlynnong) and from 


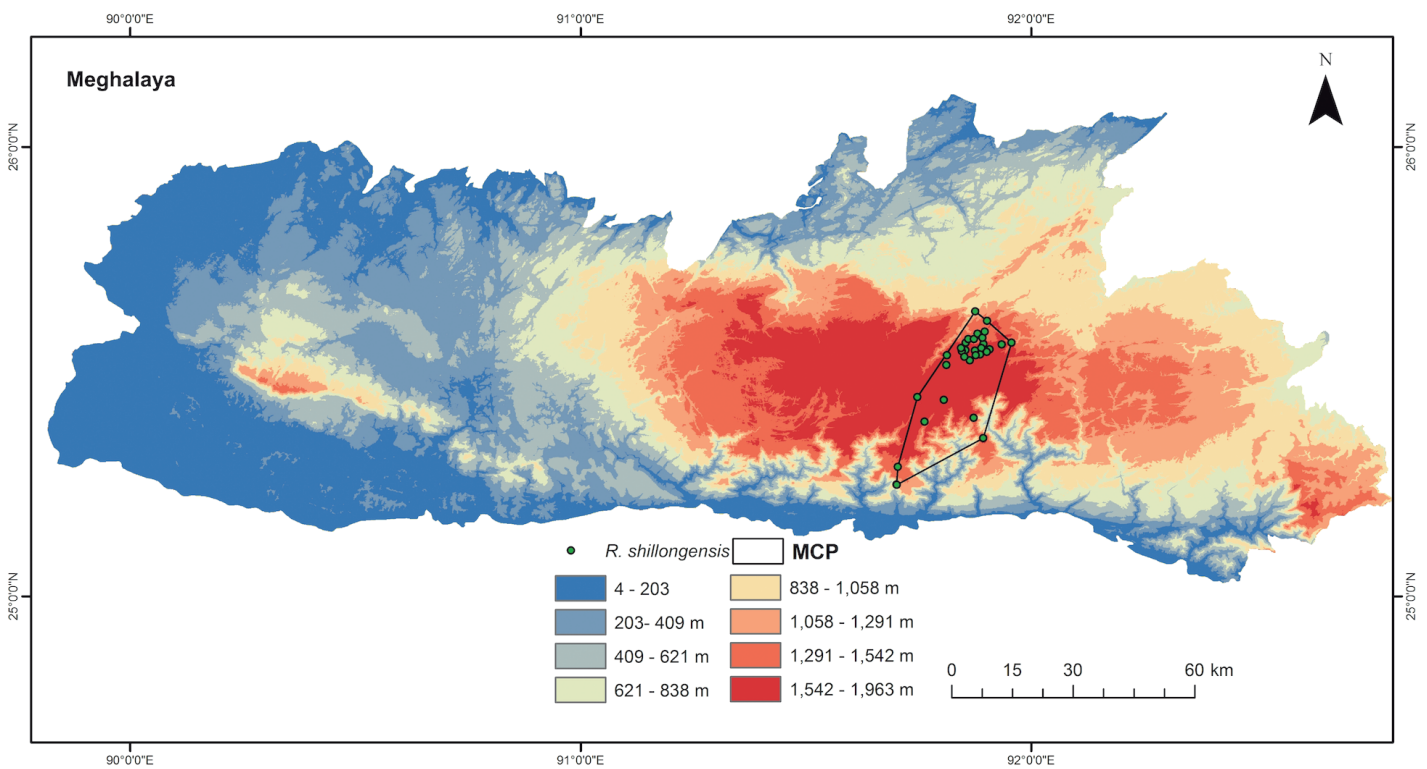

Figure 7. Current distribution map of Raorchestes shillongensis.

north (Ribhoi and Badapani) of Khasi Hills represent two separate lineages that are distinct from $R$. shillongensis. Both of these north and south locations are below $500 \mathrm{~m}$ a.s.l. Mathew and Sen (2009) reported $P$. garo from the ZSI, Risa Colony, Shillong, which is near the type locality of $R$. shillongensis. It may be misidentified because the population of $R$. shillongensis is variable in color. Nevertheless, the present molecular study reveals that the population from the Shillong is R. shillongensis. Our analyses support the findings of Vijaykumar et al. (2016) who showed that $R$. shillongensis is closely related to the Indochinese subclade of Raorchestes, rather than the clades of the Western Ghats (Raorchestes) and Southeast Asian (Philautus).

Though Northeast India is a major center of amphibian diversity, only the caecilian fauna of this region has been studied phylogenetically (Kamei et al. 2012, 2013, Biju et al. 2016). Moreover, rhacophorid frogs of Northeast India have received little attention in contrast to the members of this family in the Western Ghats. In addition, we know little about the biogeography and taxonomy of the genus Raorchestes in the Indochina. Future research on this group from the region could uncover many undescribed species.

\section{Conservation and Awareness}

Khasi Hills has about 20 named species of anurans, some with defined and others with undetermined type localities. The Shillong Plateau has 11 taxa, the type localities of which lie specifically within its biogeographical limit (Mahony et al. 2013). Among them, $R$. shillongensis is categorized as "Critically Endangered" by IUCN (http://www.iucnredlist. org) because of its narrow distribution and the decline of its habitat. Future study may extend the range of its distribution. However, illegal tree felling, unregulated mining in protected and 
unprotected areas in the state (Gilbert 2012) and in the Shillong Plateau, may have a considerable impact on the survival of amphibian fauna in the region (Mahony et al. 2013). Therefore, conservation of these remaining forests, which are the typical habitats of the threatened endemic species of the region, is urgent.

\section{Acknowledgments}

We are grateful to the Meghalaya Forest Department, Principal Chief Conservator of Forests (Wildlife) for permission to conduct this study (Reference: Number FWC/G/173/Pt111/3897-908 dt. 9.2.2016). We thank the Divisional Forest Officer and beat officers of Malki, Motinagar, and Upper Shillong beat offices for their cooperation during the survey period. Mohamed bin Zayed Species Conservation Fund provided financial support. We also thank the Director and Dean, Wildlife Institute of India, Dehradun for their constant support. Kaushik Deuti and Uttam Saikia of ZSI, and Deepak Veerappan of the NHM London provided valuable suggestions. We are grateful to Linda Trueb for critical revision of the manuscript. Anukul Nath (UNESCO, C2C, WII, Dehradun) contributed suggestions and helped to prepare the map. Bhaskar Saikia (ZSI, Shillong) and field assistants Teibor Marwein and Barik assisted us in the field. Aswika Kapoor and Samrat Sengupta produced the beautiful documentary on the species. Dr. Pratap Singh, WII for his help with acoustical data analysis. Naitik Patel and Shravana Goswami, WII, Dehradun assisted with lab work and map preparation.

\section{References}

Ahmed, M. F., A. Das, and S. K. Dutta. 2009. Amphibians and Reptiles of Northeast India: a Photographic Guide. Guwahati. Aaranyak. 170 pp.

Annandale, N. 1912. Zoological results of the Abor Expedition, 1911-1912. I. Battrachia. Records of the Indian Museum 8: 7-36.
Bee, M. A., R. Suyesh, and S. D. Biju. 2013a. Vocal behavior of the Ponmudi bush frog (Raorchestes graminirupes): repertoire and individual variation. Herpetologica 69: 22-35.

Bee, M. A., R. Suyesh, and S. D. Biju. 2013b. The vocal repertoire of Pseudophilautus kani, a shrub frog (Anura: Rhacophoridae) from the Western Ghats of India. Bioacoustics 22: 67-85.

Biju, S. D., Y. S. Shouche, A. Dubois, S. K. Dutta, and F. Bossuyt. 2010. A ground-dwelling rhacophorid frog from the highest mountain peak of the Western Ghats of India. Current Science 98: 1119-1125.

Biju, S. D., G. Senevirathne, S. Garg, S. Mahony, R. G. Kamei, A. Thomas, Y. Shouche, C. J. Raxworthy, M. Meegaskumbura, and I. Van Bocxlaer. 2016. Frankixalus, a new rhacophorid genus of tree hole breeding frogs with oophagous tadpoles. PLOS ONE 11: e0145727.

Bioacoustics Research Program. 2011. Raven Pro: Interactive Sound Analysis Software Version 1.5. URL: http:// www.birds.cornell.edu/raven. (Accessed 12 November 2016).

Boruah, B., U. Saikia, and A. Das. 2017. Reproductive behavior of Raorchestes shillongensis (Pillai and Chanda, 1973) from Meghalaya, Northeast India. Pp. 217-228 in A. Das (ed.), Diversity and Ecology of Amphibians of India. Envis bulletin: Wildlife and protected areas. Vol. 19. Dehradun. Wildlife Institute of India.

Boulenger, G. A. 1906. Description of two new Indian frogs. Journal of the Asiatic Society of Bengal 2: 385-386.

Boulenger, G. A. 1919. Descriptions of three new batrachians from the Garo Hills, Assam. Records of the Indian Museum 16: 207-208.

Bossuyt, F. and A. Dubois. 2001. A review of the frog genus Philautus Gistel, 1848 (Amphibia, Anura, Ranidae, Rhacophorinae). Zeylanica 6: 1-112.

Champion, H. G. and S. K. Seth. 1968. A Revised Survey of the Forest Types of India. Delhi. Manager of Publications, Government of India Press. 404 pp.

Chanda, S. K. 2002. Handbook, Indian amphibians. Calcutta. Zoological Survey of India. 335 pp.

Charif, R. A., A. M. Waack, and L. M. Strickman. 2010. Raven Pro 1.4 User's Manual. Ithaca. Cornell Laboratory of Ornithology. $379 \mathrm{pp}$.

Das, A., M. Chetia, S. K. Dutta, and S. Sengupta. 2013. A new species of Duttaphrynus (Anura: Bufonidae) from Northeast India. Zootaxa 3646: 336-348. 
Duellman, W. E. and L. Trueb. 1986. Biology of amphibians. New York. McGraw-Hill. 670 pp.

Edgar, R. C. 2004. MUSCLE: multiple sequence alignment with high accuracy and high throughput. Nucleic Acids Research 32: 1792-1797.

Frost, D. R. (ed.). 2017. Amphibian Species of the World: an Online Reference, Version 6.0. Electronic Database available at: http://research.amnh.org. American Museum of Natural History. (Accessed on 11 August 2017).

Gilbert, N. 2012. India's forest area in doubt. Reliance on satellite data blamed for over-optimistic estimates of forest cover. Nature 489: 14-15.

Goswami, J., D. Chutia, and S. Sudhakar. 2012. A geospatial approach to climatic zone specific effective horticultural planning in East Khasi Hills District of Meghalaya, India. Journal of Geographic Information System 4: 267-272.

Günther, A. C. L. G. 1876 “1875”. Third report on collections of Indian reptiles obtained by the British Museum. Proceedings of the Zoological Society of London 1875: 567-577.

Heyer, W. R., M. A. Donnelly, R. W. McDiarmid, L. C. Hayek, and M. S. Foster (eds.). 1994. Measuring and Monitoring Biological Diversity: Standard Methods for Amphibians. Washington. Smithsonian Institution Press. 364 pp.

Kamei, R. G., D. S. Mauro, D. J. Gower, I. Van Bocxlaer, E. Sherratt, A. Thomas, S. Babu, F. Bossuyt, M. Wilkinson, and S. D. Biju. 2012. Discovery of a new family of amphibians from northeast India with ancient links to Africa. Proceedings of the Royal Society of London B, Biological Sciences 279: 2396-2401.

Kamei, R. G., D. J. Gower, M. Wilkinson, and S. D. Biju. 2013. Systematics of the caecilian family Chikilidae (Amphibia: Gymnophiona) with the description of three new species of Chikila from northeast India. Zootaxa 3666: 401-435.

Mahony, S., S. Sengupta, R. G. Kamei, and S. D. Biju. 2011. A new low altitude species of Megophrys Kuhl and van Hasselt (Amphibia: Megophryidae), from Assam, Northeast India. Zootaxa 3059: 36-46.
Mahony, S., E. C. Teeling, and S. D. Biju. 2013. Three new species of horned frogs, Megophrys (Amphibia: Megophryidae), from Northeast India, with a resolution to the identity of Megophrys boettgeri populations reported from the region. Zootaxa 3722: $143-169$.

Mathew, R. and N. Sen. 2009. Studies on little known amphibians of Northeast India. Records of the Zoological Survey of India, Occasional Papers 293: 1-64.

Mathew, R. and N. Sen. 2010. Pictorial Guide to Amphibians of North East India. Calcutta. Zoological Survey of India. $144 \mathrm{pp}$.

Palumbi, S. R, A. P. Martin, S. L. Romano, W. O. McMillan, L. Stice, and G. Grabowski. 1991. The Simple Fool's Guide to PCR. Honolulu. Special Publications, Department of Zoology, University of Hawaii. 45 pp.

Pillai, R. S. and S. K. Chanda. 1973. Philautus shillongensis, a new frog (Ranidae) from Meghalaya, India. Proceedings of the Indian Academy of Sciences B 79: 30-36.

Purkayastha, J. and M. Matsui. 2012. A new species of Fejervarya (Anura: Dicroglossidae) from Mawphlang, northeastern India. Asian Herpetological Research 2: 31-37.

Sarkar, A. K. and D. P. Sanyal. 1985. Amphibia. Records of the Zoological Survey of India 81: 285-295.

Sarkar, A. K. and S. Ray. 2006. Amphibia. Pp. 285-316 in J. R. B. Alfred (ed.), State Fauna Series 13, Fauna of Arunachal Pradesh, Part 1. Calcutta. Zoological Survey of India.

Sondhi, S. and A. Ohler. 2011. A blue-eyed Leptobrachium (Anura: Megophryidae) from Arunachal Pradesh, India. Zootaxa 2912: 28-36.

Stamatakis, A. 2014. RAxML Version 8: a tool for phylogenetic analysis and post-analysis of large phylogenies. Bioinformatics 30: 1312-1313.

Vijayakumar, S. P., R. C. Menezes, A. Jayarajan, and K. Shanker. 2016. Glaciations, gradients, and geography: multiple drivers of diversification of bush frogs in the Western Ghats Escarpment. Proceedings of the Royal Society B 283: 20161011. 
Appendix I. Voucher numbers and GenBank accession numbers of the species used for phylogenetic analysis.

\begin{tabular}{|c|c|c|}
\hline Sl. No. & Species name & GenBank \# 16S accession numbers \\
\hline 1 & Raorchestes beddomii & JX092653.1 \\
\hline 2 & Raorchestes griet & JX092654.1 \\
\hline 3 & Raorchestes marki & JX092719.1 \\
\hline 4 & Raorchestes sp. CESF418 & JX092711.1 \\
\hline 5 & Raorchestes sp. CESF420 & JX092712.1 \\
\hline 6 & Raorchestes shillongensis (Malki Forest) & SUB3716157 \\
\hline 7 & Raorchestes shillongensis (Risa Forest) & SUB3711598 \\
\hline 8 & Raorchestes spp. (Riwai) & SUB3716694 \\
\hline 9 & Raorchestes spp. (Mawlynnong) & SUB3716575 \\
\hline 10 & Pseudophilautus kani & JX092724.1 \\
\hline 11 & Pseudophilautus amboli & JX092698.1 \\
\hline 12 & Raorchestes longchuanensis & KC465839.1 \\
\hline 13 & Philautus juliandringi & KX440538.1 \\
\hline 14 & Philautus mjobergi & KX440533.1 \\
\hline 15 & Philautus tectus & KX440528.1 \\
\hline 16 & Philautus petersi & KX440527.1 \\
\hline 17 & Philautus refugii & KX440535.1 \\
\hline 18 & Raorchestes menglaensis & GQ285676.1 \\
\hline 19 & Kurixalus eiffingeri & AY880492.1 \\
\hline
\end{tabular}

Appendix II. Gazetteer list of distribution of Raorchestes shillongensis in Meghalaya with locality records, GPS coordinates, elevation, and locality status $(P=$ Protected forest, UP $=$ Unprotected area, $T P=$ Tourist place, $C P=$ Community protected forest, $S P=$ Semi-protected area $)$.

\begin{tabular}{lccccc}
\hline Sl. No. & Latitude & Longitude & $\begin{array}{c}\text { Elevation } \\
\text { (m a.s.l.) }\end{array}$ & Locality & $\begin{array}{c}\text { Status of the } \\
\text { locality }\end{array}$ \\
\hline 1 & $25^{\circ} 32^{\prime} 20.2^{\prime \prime}$ & $91^{\circ} 51^{\prime} 3.9^{\prime \prime}$ & 1853 & Shillong Peak & $\mathrm{P}$ \\
2 & $25^{\circ} 32^{\prime} 22.3^{\prime \prime}$ & $91^{\circ} 51^{\prime} 2.5^{\prime \prime}$ & 1800 & Upper Shillong Forest & $\mathrm{P}$ \\
3 & $25^{\circ} 32^{\prime} 23.8^{\prime \prime}$ & $91^{\circ} 50^{\prime} 59.1^{\prime \prime}$ & 1791 & Upper Shillong Forest & $\mathrm{P}$ \\
4 & $25^{\circ} 32^{\prime} 26.8^{\prime \prime}$ & $91^{\circ} 50^{\prime} 59.7^{\prime \prime}$ & 1803 & Upper Shillong Forest & $\mathrm{P}$ \\
5 & $25^{\circ} 32^{\prime} 42.2^{\prime \prime}$ & $91^{\circ} 51^{\prime} 14.4^{\prime \prime}$ & 1682 & Upper Shillong Forest & $\mathrm{P}$ \\
6 & $25^{\circ} 32^{\prime} 43^{\prime \prime}$ & $91^{\circ} 51^{\prime} 13.4^{\prime \prime}$ & 1711 & Upper Shillong Forest & $\mathrm{P}$ \\
7 & $25^{\circ} 32^{\prime} 54^{\prime \prime}$ & $91^{\circ} 51^{\prime} 14.6^{\prime \prime}$ & 1694 & Upper Shillong Forest & $\mathrm{P}$ \\
9 & $25^{\circ} 32^{\prime} 53.5^{\prime \prime}$ & $91^{\circ} 51^{\prime} 3.9^{\prime \prime}$ & 1676 & Upper Shillong Forest & $\mathrm{P}$ \\
10 & $25^{\circ} 32^{\prime} 44.7^{\prime \prime}$ & $91^{\circ} 50^{\prime} 46.1^{\prime \prime}$ & 1781 & Upper Shillong Forest & $\mathrm{P}$ \\
11 & $25^{\circ} 32^{\prime} 51.9^{\prime \prime}$ & $91^{\circ} 51^{\prime} 1.1^{\prime \prime}$ & 1747 & Upper Shillong Forest & $\mathrm{P}$ \\
\hline
\end{tabular}


Appendix II. Continued.

\begin{tabular}{|c|c|c|c|c|c|}
\hline Sl. No. & Latitude & Longitude & $\begin{array}{r}\text { Elevation } \\
\text { (m a.s.l.) }\end{array}$ & Locality & $\begin{array}{c}\text { Status of the } \\
\text { locality }\end{array}$ \\
\hline 13 & $25^{\circ} 33^{\prime} 16.5^{\prime \prime}$ & $91^{\circ} 53 ' 59.1^{\prime \prime}$ & 1707 & Motinagar Forest & $\mathrm{P}$ \\
\hline 14 & $25^{\circ} 33^{\prime} 24.7^{\prime \prime}$ & $91^{\circ} 53 ' 56.4^{\prime \prime}$ & 1634 & Motinagar Forest & $\mathrm{P}$ \\
\hline 15 & $25^{\circ} 33^{\prime} 33.6^{\prime \prime}$ & $91^{\circ} 53^{\prime} 51.8^{\prime \prime}$ & 1606 & Motinagar Forest & $\mathrm{P}$ \\
\hline 16 & $25^{\circ} 33^{\prime} 23.7^{\prime \prime}$ & $91^{\circ} 53^{\prime} 46.3^{\prime \prime}$ & 1625 & Motinagar Forest & $\mathrm{P}$ \\
\hline 17 & $25^{\circ} 33^{\prime} 25.8^{\prime \prime}$ & $91^{\circ} 53^{\prime} 54.2^{\prime \prime}$ & 1607 & Motinagar Forest & $\mathrm{P}$ \\
\hline 18 & $25^{\circ} 33^{\prime} 19.8^{\prime \prime}$ & $91^{\circ} 53 ' 50.4^{\prime \prime}$ & 1659 & Motinagar Forest & $\mathrm{P}$ \\
\hline 19 & $25^{\circ} 33^{\prime} 16.3^{\prime \prime}$ & $91^{\circ} 53 ' 51.7^{\prime \prime}$ & 1675 & Motinagar Forest & $\mathrm{P}$ \\
\hline 20 & $25^{\circ} 33^{\prime} 14.6^{\prime \prime}$ & $91^{\circ} 53^{\prime} 51.5^{\prime \prime}$ & 1707 & Motinagar Forest & $\mathrm{P}$ \\
\hline 21 & $25^{\circ} 33^{\prime} 10.8^{\prime \prime}$ & $91^{\circ} 53^{\prime} 52.7^{\prime \prime}$ & 1747 & MotinagarForest & $\mathrm{P}$ \\
\hline 22 & $25^{\circ} 33^{\prime} 6.5^{\prime \prime}$ & $91^{\circ} 53^{\prime} 46.6^{\prime \prime}$ & 1783 & Laitkor Forest & $\mathrm{P}$ \\
\hline 23 & $25^{\circ} 33^{\prime} 39.3^{\prime \prime}$ & $91^{\circ} 53^{\prime} 7.7^{\prime \prime}$ & 1593 & Malki Forest Office & $\mathrm{P}$ \\
\hline 24 & $25^{\circ} 33^{\prime} 29.9^{\prime \prime}$ & $91^{\circ} 53^{\prime} 3.8^{\prime \prime}$ & 1588 & Malki Stream & $\mathrm{P}$ \\
\hline 25 & $25^{\circ} 33^{\prime} 25.8^{\prime \prime}$ & $91^{\circ} 53^{\prime} 4.7^{\prime \prime}$ & 1611 & Malki Stream & $\mathrm{P}$ \\
\hline 26 & $25^{\circ} 33^{\prime} 22.4^{\prime \prime}$ & $91^{\circ} 53^{\prime} 5.5^{\prime \prime}$ & 1613 & Malki Stream & $\mathrm{P}$ \\
\hline 27 & $25^{\circ} 33^{\prime} 31.7^{\prime \prime}$ & $91^{\circ} 53^{\prime} 0^{\prime \prime}$ & 1599 & Malki Stream & $\mathrm{P}$ \\
\hline 28 & $25^{\circ} 33^{\prime} 31.2^{\prime \prime}$ & $91^{\circ} 53^{\prime} 6.6^{\prime \prime}$ & 1621 & Laitkor Forest & $\mathrm{P}$ \\
\hline 29 & $25^{\circ} 33^{\prime} 33.7^{\prime \prime}$ & $91^{\circ} 53^{\prime} 11^{\prime \prime}$ & 1599 & Laitkor Forest & $\mathrm{P}$ \\
\hline 30 & $25^{\circ} 33^{\prime} 18.4^{\prime \prime}$ & $91^{\circ} 53^{\prime} 15.6^{\prime \prime}$ & 1656 & Laitkor Forest & $\mathrm{P}$ \\
\hline 31 & $25^{\circ} 33^{\prime} 9.5^{\prime \prime}$ & $91^{\circ} 53^{\prime} 22.6^{\prime \prime}$ & 1785 & Laitkor Forest & $\mathrm{P}$ \\
\hline 32 & $25^{\circ} 32^{\prime} 59.7^{\prime \prime}$ & $91^{\circ} 53^{\prime} 20.8^{\prime \prime}$ & 1807 & Laitkor Forest & $\mathrm{P}$ \\
\hline 33 & $25^{\circ} 32^{\prime} 50.4^{\prime \prime}$ & $91^{\circ} 53^{\prime} 16.3^{\prime \prime}$ & 1882 & Laitkor Forest & $\mathrm{P}$ \\
\hline 34 & $25^{\circ} 32^{\prime} 39.7^{\prime \prime}$ & $91^{\circ} 53^{\prime} 18.8^{\prime \prime}$ & 1884 & Near Laitkor Nursing Centre & $\mathrm{P}$ \\
\hline 35 & $25^{\circ} 33^{\prime} 24.4^{\prime \prime}$ & $91^{\circ} 53^{\prime} 33.9^{\prime \prime}$ & 1589 & Risa Forest Stream & $\mathrm{P}$ \\
\hline 36 & $25^{\circ} 33^{\prime} 15.8^{\prime \prime}$ & $91^{\circ} 53^{\prime} 38.9^{\prime \prime}$ & 1639 & Risa Forest Stream & $\mathrm{P}$ \\
\hline 37 & $25^{\circ} 33^{\prime} 11.3^{\prime \prime}$ & $91^{\circ} 53^{\prime} 35^{\prime \prime}$ & 1667 & Risa Forest Stream & $\mathrm{P}$ \\
\hline 38 & $25^{\circ} 33^{\prime} 12^{\prime \prime}$ & $91^{\circ} 53^{\prime} 33^{\prime \prime}$ & 1700 & Risa Forest & $\mathrm{P}$ \\
\hline 39 & $25^{\circ} 33^{\prime} 18.2^{\prime \prime}$ & $91^{\circ} 53^{\prime} 36.2^{\prime \prime}$ & 1655 & Risa Forest & $\mathrm{P}$ \\
\hline 40 & $25^{\circ} 33^{\prime} 10.6^{\prime \prime}$ & $91^{\circ} 53^{\prime} 27^{\prime \prime}$ & 1770 & Risa Forest & UP \\
\hline 41 & $25^{\circ} 33^{\prime} 42^{\prime \prime}$ & $91^{\circ} 53 ' 2.4^{\prime \prime}$ & 1559 & Malki & $\mathrm{P}$ \\
\hline 42 & $25^{\circ} 34^{\prime} 50.6^{\prime \prime}$ & $91^{\circ} 53^{\prime} 17.5^{\prime \prime}$ & 1418 & Orchid Hotel (Polo) & UP \\
\hline 43 & $25^{\circ} 33^{\prime} 13^{\prime \prime}$ & $91^{\circ} 53^{\prime} 32.3^{\prime \prime}$ & 1719 & Risa Forest & $\mathrm{P}$ \\
\hline 44 & $25^{\circ} 33^{\prime} 11^{\prime \prime}$ & $91^{\circ} 53^{\prime} 26.2^{\prime \prime}$ & 1762 & Risa Forest & $\mathrm{P}$ \\
\hline 45 & $25^{\circ} 33^{\prime} 9.4^{\prime \prime}$ & $91^{\circ} 53^{\prime} 22.6^{\prime \prime}$ & 1784 & Risa Forest & $\mathrm{P}$ \\
\hline 46 & $25^{\circ} 33^{\prime} 13.6^{\prime \prime}$ & $91^{\circ} 53 ' 23.4^{\prime \prime}$ & 1753 & Risa Forest & $\mathrm{P}$ \\
\hline 47 & $25^{\circ} 14^{\prime} 56^{\prime \prime}$ & $91^{\circ} 42^{\prime} 3.1^{\prime \prime}$ & 1171 & Sohra & $\mathrm{P}$ \\
\hline 48 & $25^{\circ} 14 ' 54.6^{\prime \prime}$ & $91^{\circ} 42^{\prime} 6.2^{\prime \prime}$ & 1101 & Sohra & $\mathrm{P}$ \\
\hline 49 & $25^{\circ} 33^{\prime} 52.9^{\prime \prime}$ & $91^{\circ} 51^{\prime} 15.4^{\prime \prime}$ & 1607 & Mawphlang Sacred Groove & $\mathrm{CP}$ \\
\hline
\end{tabular}


Boruah et al.

Appendix II. Continued.

\begin{tabular}{|c|c|c|c|c|c|}
\hline Sl. No. & Latitude & Longitude & $\begin{array}{r}\text { Elevation } \\
\text { (m a.s.l.) }\end{array}$ & Locality & $\begin{array}{c}\text { Status of the } \\
\text { locality }\end{array}$ \\
\hline 50 & $25^{\circ} 33^{\prime} 10^{\prime \prime}$ & $91^{\circ} 50 ' 39.6^{\prime \prime}$ & 1723 & Mawphlang Sacred Groove & $\mathrm{CP}$ \\
\hline 51 & $25^{\circ} 26^{\prime} 36.2^{\prime \prime}$ & $91^{\circ} 44^{\prime} 50.7^{\prime \prime}$ & 1815 & Mawphlang Sacred Groove & $\mathrm{CP}$ \\
\hline 52 & $25^{\circ} 26^{\prime} 14.5^{\prime \prime}$ & $91^{\circ} 48^{\prime} 22^{\prime \prime}$ & 1855 & Cherrapunji Road & UP \\
\hline 53 & $25^{\circ} 23^{\prime} 19.7^{\prime \prime}$ & $91^{\circ} 45^{\prime} 47.4^{\prime \prime}$ & 1757 & Cherrapunji Road & UP \\
\hline 54 & $25^{\circ} 16^{\prime} 31.67^{\prime \prime}$ & $91^{\circ} 41^{\prime} 10.03^{\prime \prime}$ & - & Nohkalikai Falls & $\mathrm{TP}$ \\
\hline 55 & $25^{\circ} 23^{\prime} 51.4^{\prime \prime}$ & $91^{\circ} 52 ' 20.4^{\prime \prime}$ & 1570 & Mawllynnong Road & UP \\
\hline 56 & $25^{\circ} 21^{\prime} 8.4^{\prime \prime}$ & $91^{\circ} 53^{\prime} 36.5^{\prime \prime}$ & 1555 & Pynursla & UP \\
\hline 57 & $25^{\circ} 30^{\prime} 54.2^{\prime \prime}$ & $91^{\circ} 48^{\prime} 42.4^{\prime \prime}$ & 1709 & Upper Shillong & UP \\
\hline 58 & $25^{\circ} 32^{\prime} 11.9^{\prime \prime}$ & $91^{\circ} 48^{\prime} 46^{\prime \prime}$ & 1675 & Sado, Upper Shillong & $\mathrm{P}$ \\
\hline 59 & $25^{\circ} 32^{\prime} 49.9^{\prime \prime}$ & $91^{\circ} 52 ' 29.5^{\prime \prime}$ & 1912 & Shillong Peak & $\mathrm{P}$ \\
\hline 60 & $25^{\circ} 33^{\prime} 55.4^{\prime \prime}$ & $91^{\circ} 51^{\prime} 35.8^{\prime \prime}$ & 1557 & Upper Shillong & $\mathrm{P}$ \\
\hline 61 & $25^{\circ} 34^{\prime} 8.5^{\prime \prime}$ & $91^{\circ} 51^{\prime} 50.8^{\prime \prime}$ & 1497 & Upper Shillong & $\mathrm{P}$ \\
\hline 62 & $25^{\circ} 34^{\prime} 21.3^{\prime \prime}$ & $91^{\circ} 51^{\prime} 36.3^{\prime \prime}$ & 1536 & Nongsehrim & UP \\
\hline 63 & $25^{\circ} 34^{\prime} 21.6^{\prime \prime}$ & $91^{\circ} 52^{\prime} 22.5^{\prime \prime}$ & 1507 & Relebang & UP \\
\hline 64 & $25^{\circ} 34^{\prime} 21.6^{\prime \prime}$ & $91^{\circ} 52^{\prime} 41.4^{\prime \prime}$ & 1500 & Police Bazar & UP \\
\hline 65 & $25^{\circ} 34^{\prime} 29.5^{\prime \prime}$ & $91^{\circ} 52^{\prime} 46^{\prime \prime}$ & 1464 & Police Bazar & UP \\
\hline 66 & $25^{\circ} 35^{\prime} 4.1^{\prime \prime}$ & $91^{\circ} 52^{\prime} 50.9^{\prime \prime}$ & 1431 & Lawmali & UP \\
\hline 67 & $25^{\circ} 34^{\prime} 31.3^{\prime \prime}$ & $91^{\circ} 533^{\prime \prime}$ & 1480 & Municipal & UP \\
\hline 68 & $25^{\circ} 34^{\prime} 48.4^{\prime \prime}$ & $91^{\circ} 53 \prime 25.3^{\prime \prime}$ & 1431 & Polo & UP \\
\hline 69 & $25^{\circ} 34^{\prime} 43.8^{\prime \prime}$ & $91^{\circ} 53^{\prime} 35.2^{\prime \prime}$ & 1440 & Polo & UP \\
\hline 70 & $25^{\circ} 35^{\prime} 21.3^{\prime \prime}$ & $91^{\circ} 53^{\prime} 47.8^{\prime \prime}$ & 1425 & Golf Link & UP \\
\hline 71 & $25^{\circ} 36^{\prime} 46.6^{\prime \prime}$ & $91^{\circ} 54^{\prime} 7.2^{\prime \prime}$ & 1400 & Northeast Hill University & SP \\
\hline 72 & $25^{\circ} 17^{\prime} 17.1^{\prime \prime}$ & $91^{\circ} 42^{\prime} 13.6^{\prime \prime}$ & 1418 & Dainthlen & UP \\
\hline 73 & $25^{\circ} 38^{\prime} 4^{\prime \prime}$ & $91^{\circ} 52^{\prime} 32.6^{\prime \prime}$ & 1087 & Mawlai Forest & $\mathrm{P}$ \\
\hline 74 & $25^{\circ} 33^{\prime} 53.6^{\prime \prime}$ & $91^{\circ} 57^{\prime} 23.1^{\prime \prime}$ & 1475 & Sweet Fall & $\mathrm{TP}$ \\
\hline 75 & $25^{\circ} 33^{\prime} 37.3^{\prime \prime}$ & $91^{\circ} 56^{\prime} 3.2^{\prime \prime}$ & 1660 & Everliving Museum & UP \\
\hline 76 & $25^{\circ} 32 ' 58.3^{\prime \prime}$ & $91^{\circ} 54 ' 27^{\prime \prime}$ & 1754 & Laitkor & UP \\
\hline 77 & $25^{\circ} 32^{\prime} 17.4^{\prime \prime}$ & $91^{\circ} 53^{\prime} 12.5^{\prime \prime}$ & 1872 & Laitkor & UP \\
\hline 78 & $25^{\circ} 32^{\prime} 38.2^{\prime \prime}$ & $91^{\circ} 54^{\prime} 5.2^{\prime \prime}$ & 1829 & Laitkor & UP \\
\hline 79 & $25^{\circ} 32^{\prime} 11.8^{\prime \prime}$ & $91^{\circ} 52^{\prime} 37.3^{\prime \prime}$ & 1879 & Laitkor & UP \\
\hline 80 & $25^{\circ} 31^{\prime} 31.2^{\prime \prime}$ & $91^{\circ} 51^{\prime} 49.7^{\prime \prime}$ & 1847 & Laitkor & UP \\
\hline 81 & $25^{\circ} 32^{\prime} 0.5^{\prime \prime}$ & $91^{\circ} 51^{\prime} 6.3^{\prime \prime}$ & 1924 & Shillong Peak & $\mathrm{TP}$ \\
\hline 82 & $25^{\circ} 32^{\prime} 13.23^{\prime \prime}$ & $91^{\circ} 49^{\prime} 20.85^{\prime \prime}$ & - & Elephant Falls & $\mathrm{TP}$ \\
\hline
\end{tabular}

